\title{
Supplementary methods for "Pharmacological targeting of MTHFD2 suppresses acute myeloid leukemia by inducing thymidine depletion and replication stress"
}

Nadilly Bonagas

Nina Gustafsson

Martin Henriksson

Petra Marttila

Robert Gustafsson

Elisée Wiita

Sanjay Borhade

Alanna Green

Karl Vallin

Antonio Sarno

Richard Svensson

Camilla Göktürk

Therese Pham

Ann-Sofie Jemth

Olga Loseva

Victoria Cookson

Nicole Kiweler

Lars Sandberg

Azita Rasti

Judith Unterlass

Martin Haraldsson

Yasmin Andersson

Emma Scaletti

Christoffer Bengtsson

Cynthia Paulin

Kumar Sanjiv

Eldar Abdurakhmanov

Linda Pudelko

Ben Kunz

Matthieu Desroses

Petar Iliev

Katarina Färnegårdh 
Andreas Krämer

Neeraj Garg

Maurice Michel

Sara Häggblad

Malin Jarvius

Christina Kalderén

Amanda Bögedahl Jensen

Ingrid Almlöf

Stella Karsten

Si Min Zhang

Maria Häggblad

Anders Eriksson

Jianping Liu

Björn Glinghammar

Natalia Nekhotiaeva

Fredrik Klingegård

Tobias Koolmeister

Ulf Martens

Sabin Llona-Minguez

Ruth Moulson

Helena Nordström

Vendela Parrow

Leif Dahllund

Birger Sjöberg

Irene Vargas

Duy Duc Vo

Johan Wannberg

Stefan Knapp

Hans Krokan

Per Arvidsson

Martin Scobie

Johannes Meiser

Pål Stenmark

Ulrika Warpman Berglund

Evert Homan

Thomas Helleday ( $\boldsymbol{\nabla}$ thomas.helleday@scilifelab.se )

Method Article

Keywords:

Posted Date: March 8th, 2022 
DOl: https://doi.org/10.21203/rs.3.pex-1730/v1

License: (c) (1) This work is licensed under a Creative Commons Attribution 4.0 International License. Read Full License 


\section{Abstract}

Supplementary methods for the article "Pharmacological targeting of MTHFD2 suppresses acute myeloid leukemia by inducing thymidine depletion and replication stress".

\section{Procedure}

Modified comet assay with uracil-DNA glycosylase (UNG). Briefly, THP-1 cells were treated with DMSO, MTHFD2i (TH7299 3 M, TH9028 50 nM, TH9619 50 nM) or reference compounds (all-trans retinoic acid, ATRA $1 \mu \mathrm{M}$, methotrexate, MTX $50 \mathrm{nM}$ ) for $16 \mathrm{~h}$, harvested and washed in PBS, then mixed with $1.2 \%$ lowmelting-point agarose (Sigma Aldrich) at $37^{\circ} \mathrm{C}$ and embedded on $1 \%$ agarose-coated Superfrost slides (ThermoFisher Scientific). Subsequent steps were carried out away from light. Slides were submerged in lysis buffer (2.25 M NaCl, $115 \mathrm{mM}$ EDTA, $9 \mathrm{mM}$ Tris, 10\% DMSO, 1\% Triton X-100, NaOH to $\mathrm{pH} 10$ ) for $2 \mathrm{~h}$ at room temperature, washed $3 x$ with enzyme buffer ( $40 \mathrm{mM} \mathrm{HEPES,} 100 \mathrm{mM} \mathrm{KCl}, 0.5 \mathrm{mM}$ EDTA, 200 $\mathrm{mg} / \mathrm{L} \mathrm{BSA}, \mathrm{KOH}$ to $\mathrm{pH}$ 8), then treated with uracil-DNA glycosylase (New England Biolabs, UNG 0.1 unit/slide diluted in enzyme buffer) or enzyme buffer only for $1 \mathrm{~h}$ at $37^{\circ} \mathrm{C}$. Slides were denatured in electrophoresis buffer ( $1 \mathrm{mM}$ EDTA, $300 \mathrm{mM} \mathrm{NaOH})$ for $30 \mathrm{~min}$ at room temperature, then subjected to 25 $V$ and $300 \mathrm{~mA}$ for $30 \mathrm{~min}$ at $4{ }^{\circ} \mathrm{C}$ in a comet assay tank (Thistle Scientific), and followed by incubation in neutralization buffer ( $400 \mathrm{mM}$ Tris, $\mathrm{HCl}$ to $\mathrm{pH} 7.5)$ for $45 \mathrm{~min}$ at room temperature. For image acquisition, slides were stained with SYBR ${ }^{\circledR}$ Gold Nucleic Acid Gel Stain (ThermoFisher) and visualized at $488 \mathrm{~nm}$ and 10x magnification using a Zeiss Axiovert 35 inverted fluorescence microscope. Comet tail moment for 200 cells per condition was measured live using Comet Assay IV software (Instem).

Recombinant proteins. Cloning, expression, and purification of human MTHFD2 and MTHFD1 dehydrogenase/cyclohydrolase (DC) proteins were performed as described in Gustafsson, R. et al. Cancer Res. 2017 Feb 15;77(4):937-948 (doi: 10.1158/0008-5472.CAN-16-1476). Mouse MTHFD2 was produced as described for human MTHFD2. MTHFD2L cDNA encoding protein lacking mitochondrial signal peptide (AA 50-347) was cloned into pET22b vector and the construct was transformed into $E$. coli Arctic Express (DE3) competent cells. The protein expression was induced by $0.5 \mathrm{mM} \mathrm{IPTG}$ at $13^{\circ} \mathrm{C}$ for 20 hours. Collected cells were dissolved in BugBuster protein extraction reagent (Merck/Novagen) supplemented with complete protease inhibitor cocktail (Roche), Benzonase ${ }^{\circledR}$ Nuclease (Novagen) and $0.35 \mathrm{mg} / \mathrm{ml}$ lysozyme (Sigma-Aldrich). After rotation for $20 \mathrm{~min}$ at RT the suspension was centrifuged, and the supernatant was applied on a Talon column (GE Healthcare) equilibrated with $50 \mathrm{mM}$ Tris-HCl, $\mathrm{pH}$ 8.0, $100 \mathrm{mM} \mathrm{KCl}, 5 \mathrm{mM} \mathrm{MgCl}_{2}, 5 \%$ glycerol buffer. The bound proteins were eluted with linear $0 \mathrm{mM}-500 \mathrm{mM}$ imidazole gradient. The fractions containing MTHFD2L were dialyzed against $50 \mathrm{mM}$ Tris-HCl, $\mathrm{pH}$ 8.0, $100 \mathrm{mM} \mathrm{KCl}, 5 \mathrm{mM} \mathrm{MgCl} 2,10 \%$ glycerol, $0.5 \mathrm{mM}$ TCEP buffer. His-tag was cleaved off and removed by passing the protein over a HisTrap column. MTHFD2L was dialyzed against $20 \mathrm{mM}$ Tris-HCl, pH 8.2, 20 $\mathrm{mM} \mathrm{KCl}, 5 \mathrm{mM} \mathrm{MgCl}_{2}, 10 \%$ glycerol, $1 \mathrm{mM}$ TCEP buffer and loaded onto an anion-exchange monoQ-HP column (GE Healthcare) equilibrated with the same buffer. The bound proteins were eluted with linear 20 
$\mathrm{mM}-800 \mathrm{mM} \mathrm{KCl}$ gradient. Fractions with purified MTHFD2L were combined, protein concentration was determined by Bradford assay with Coomassie Plus Protein Kit (Thermo Scientific) and BSA as protein standard. MTHFD2L protein was stored at $-20^{\circ} \mathrm{C}$ in $20 \mathrm{mM}$ Tris- $\mathrm{HCl}, \mathrm{pH} 8.2,100 \mathrm{mM} \mathrm{KCl}, 5 \mathrm{mM} \mathrm{MgCl} 2,1$ mM TCEP, 40\% glycerol buffer. SHMT1, SHMT2, and TYMS proteins were purified by the Protein Science Facility at the Karolinska Institutet. DHFR was purchased from Sigma Aldrich. Uracil DNA glycosylase was purchased from New England Biolabs (Cat. \# M0280).

MTHFD2 routine inhibition assay. To determine $\mathrm{IC}_{50}$ values of a compound, an 11-point dose-response curve with 3-fold difference in concentration between points was generated by using an acoustic dispenser from Labcyte (Echo 550 Liquid handler). Each assay point was run in duplicate and the assay was performed in a white ProxiPlate low-volume 384-well plates (Perklin Elmer, Cat \# 6008280). DMSO was used as negative control. The serial dilution in DMSO, from compound DMSO stock solution, was created by dispensing from a 384-well low dead volume microplate (Labcyte, Cat \# LP-0200,) and a 384well polypropylene microplate 2.0 (Labcyte, Cat \# PP-0200,). The assay buffer consisted of $50 \mathrm{mM}$ Tris (pH 8.0), $100 \mathrm{mM} \mathrm{NaCl}, 25 \mathrm{mM} \mathrm{NaPi}, 5 \mathrm{mM} \mathrm{MgCl}_{2}, 2 \mathrm{mM}$ 2-Mercaptoethanol, $250 \mu \mathrm{M} \mathrm{NAD}^{+}$and $0.005 \%$ Tween 20. NAD (P)H-Glo ${ }^{T M}$ detection reagent was purchased from Promega (Cat \# G9061), NAD ${ }^{+}$from Sigma (Cat \# N7004) and folitixorin from Toronto Research Chemicals (Cat \# F680350). Working solution of folitixorin $(0.2 \%$ DMSO) contained $10 \mu \mathrm{M}$ folitixorin in assay buffer. MTHFD2 protein was diluted to $6.84 \mathrm{nM}(0.24 \mu \mathrm{g} / \mathrm{mL})$ in assay buffer. A total of $2.5 \mu \mathrm{L} 6.84 \mathrm{nM}$ enzyme was preincubated with compound or DMSO for 10 minutes. The enzymatic reaction was initiated by adding $2.5 \mu \mathrm{L} 10 \mu \mathrm{M}$ folitixorin. For background control, $5 \mu \mathrm{L} 250 \mu \mathrm{M}$ NAD ${ }^{+}$buffer was added to the wells in column 24 . After 15 minutes reaction, $5 \mu \mathrm{L} \mathrm{NAD(P)H-Glo} \mathrm{detection} \mathrm{reagent} \mathrm{(Cat} \mathrm{\#} \mathrm{G9061)} \mathrm{was} \mathrm{dispensed} \mathrm{in} \mathrm{all} \mathrm{wells} \mathrm{and}$ the plate was incubated for 60 minutes. Luminescence was measured in a Hidex Sense plate reader for 1 $\mathrm{sec} /$ well. The light signal produced is proportional to the amount of $\mathrm{NAD}(\mathrm{P}) \mathrm{H}$ in the sample. $\mathrm{IC}_{50}$ values were calculated using a four Parameter Logistic Model or Sigmoidal Dose-Response Model in XLfit 5 (IDBS Software).

MTHFD2L inhibition assay. The assay buffer consisted of $50 \mathrm{mM}$ Tris (pH 8.0), $100 \mathrm{mM} \mathrm{KCl}, 5 \mathrm{mM}$ $\mathrm{MgCl}_{2}, 2 \mathrm{mM}$ 2-Mercaptoethanol, 5\% Glycerol, $100 \mu \mathrm{M} \mathrm{NADP}^{+}$and $0.005 \%$ Tween 20. NADP ${ }^{+}$was purchased from Sigma (Cat \# N5755). Working solution of folitixorin (2\% DMSO) contained $80 \mu \mathrm{M}$ folitixorin in assay buffer. MTHFD2L protein was diluted to $200 \mathrm{nM}(6.5 \mu \mathrm{g} / \mathrm{mL})$ in assay buffer. The assay was performed as for MTHFD2 but in white non-binding surface 384-well plates (Corning, Cat \# 3824). For background control, $5 \mu \mathrm{L} 100 \mu \mathrm{M} \mathrm{NADP}{ }^{+}$and $40 \mu \mathrm{M}$ folitixorin in assay buffer were added to control wells. 
MTHFD1 inhibition assay. The assay buffer consisted of $25 \mathrm{mM}$ MOPS (pH 7.3), $0.5 \mathrm{mM}$ TCEP, $400 \mu \mathrm{M}$ $\mathrm{NADP}^{+}$and $0.005 \%$ TritonX100. NADP ${ }^{+}$was purchased from Sigma (Cat \# N5755). Working solution of folitixorin (1.2\% DMSO) contained $60 \mu \mathrm{M}$ folitixorin in assay buffer. MTHFD2L protein was diluted to 0.5 $\mathrm{nM}(0.017 \mu \mathrm{g} / \mathrm{mL})$ in assay buffer. The assay was performed as for MTHFD2 but in white non-binding surface 384-well plates (Corning, Cat \# 3824) and with the addition of $1 \mu \mathrm{L}$ menadione $2.75 \mathrm{mM}$ (Sigma, Cat \# M5625) in 20\% DMSO 10 min before reading. For background control, $5 \mu \mathrm{L} 400 \mu \mathrm{M} \mathrm{NADP}{ }^{+}$and 30 $\mu \mathrm{M}$ folitixorin in assay buffer were added to control wells.

DHFR inhibition assay. Inhibition of DHFR was measured using the Dihydrofolate Reductase Assay Kit purchased from Sigma Aldrich (Cat \# CS0340) following manufacturer's instructions. Compounds were dissolved to $10 \mathrm{mM}$ stock solutions in 10x assay buffer provided in the kit and screened at final concentrations of $100 \mu \mathrm{M}$. Methotrexate $1 \mu \mathrm{M}$ was used as positive control, which gave $100 \%$ inhibition.

TYMS inhibition assay. Inhibition of TYMS was measured as previously described ${ }^{76}$. Enzymatic activity was measured spectrophotometrically at $340 \mathrm{~nm}$ by monitoring the absorbance change during the conversion of 5,10-methylenetetrahydrofolate to dihydrofolate using a Hidex Sense plate reader. Measurements were carried out at room temperature in a buffer of $50 \mathrm{mM}$ Tris at pH 7.5 and $150 \mathrm{mM}$ $\mathrm{NaCl}$. Initial reaction rates were measured with $50 \mathrm{nM}$ of purified protein, $250 \mu \mathrm{M} 5,10$ methylenetetrahydrofolate and $100 \mu \mathrm{M}$ dUMP in the presence of compounds $(100 \mu \mathrm{M})$ using the same amount of DMSO as in control. Raltitrexed $(100 \mu \mathrm{M})$ was used as positive control, giving $100 \%$ inhibition. Initial rates and activity were analyzed using Prism (GraphPad Software).

SHMT1/2 inhibition assays. Inhibition of SHMT1 and SHMT2 was measured as previously described ${ }^{77}$. Compounds were tested at $100 \mu \mathrm{M}$ and lometrexol $(100 \mu \mathrm{M})$ was used as positive control, yielding $63 \%$ and 50\% inhibition of SHMT1 and SHMT2 respectively.

\section{MTHFD2 high-throughput screening (HTS)}

The assay buffer consisted of $50 \mathrm{mM}$ Tris (pH 8.0), $100 \mathrm{mM} \mathrm{NaCl}, 25 \mathrm{mM} \mathrm{NaPi}, 5 \mathrm{mM} \mathrm{MgCl}$, $2 \mathrm{mM} \beta$ mercaptoethanol, $0.005 \%$ Tween 20 and $0.03 \%$ BSA. NAD $(\mathrm{P}) \mathrm{H}-\mathrm{GlO}^{\mathrm{TM}}$ detection reagent was purchased from Promega (Cat \# G9062), NAD ${ }^{+}$from Sigma (Cat \# N7004) and folitixorin from Toronto Research

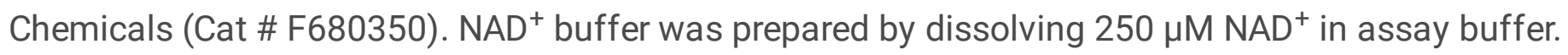
DMSO stock of folitixorin comprised $0.5 \mathrm{mM}$ folitixorin in DMSO. Working solution of folitixorin $(2 \%$ DMSO) contained $10 \mu \mathrm{M}$ folitixorin in assay buffer. MTHFD2 protein was diluted to $0.2 \mu \mathrm{g} / \mathrm{ml}$ in NAD ${ }^{+}$ 
buffer. The assay was then run according to the following consecutive steps: (1) $5 \mathrm{~nL} 10 \mathrm{mM}$ compounds were transferred using the Echo550 acoustic dispenser into 384-ProxiPlates in columns 1-22. In column 23, $5 \mathrm{~nL}$ and $50 \mathrm{~nL}$ of $10 \mathrm{mM} \mathrm{LY} 345899$ in DMSO were transferred to 3 wells each to give final concentrations of $10 \mu \mathrm{M}$ and $100 \mu \mathrm{M}$ in triplicate. DMSO $5 \mathrm{~nL}$ was transferred to the remaining wells in column 23 (DMSO wells) and to column 24 (background wells); (2) A $0.5 \mathrm{mM}$ folitixorin solution was then

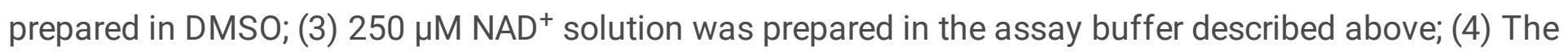
$0.5 \mathrm{mM}$ folitixorin DMSO solution was diluted 50 times in NAD ${ }^{+}$buffer to a final concentration of $10 \mu \mathrm{M}$; (5) the MTHFD2 enzyme was diluted to $0.2 \mu \mathrm{g} / \mathrm{ml}$ in the NAD ${ }^{+}$buffer and kept cold on ice; (6) $5 \mu \mathrm{NAD}^{+}$ buffer was dispensed in the background wells of column 24 , and the plates were kept on ice, until the assay was run at room temperature; (7) $2.5 \mu \mathrm{l} 0.2 \mu \mathrm{g} / \mathrm{ml}$ enzyme in NAD ${ }^{+}$buffer was dispensed with a Multidrop dispenser in columns 1-23. The plates were centrifuged at $1000 \mathrm{rpm} 1 \mathrm{~min}$, and the mixture was allowed to pre-incubate for $10 \mathrm{~min}$; (8) $2.5 \mu \mathrm{l}$ of $10 \mu \mathrm{M}$ folitixorin was then added with the Multidrop dispenser in columns 1-23, and the mixture was incubated for $15 \mathrm{~min}$; (10) $5 \mu \mathrm{l}$ of Promega NAD(P)H$\mathrm{Glo}^{\mathrm{TM}}$ detection reagent (mixed according to manufacturer) was then dispensed in all wells using a Multidrop dispenser; (11) the detection mixtures was incubated for $1 \mathrm{~h}$; (12) luminescence was read using a Hidex Sense plate reader.

\section{Synthesis of TH9028}

\section{Methyl (2S)-2-[(5-aminopyridin-2-yl)formamido]-4-[1-(2-cyanoethyl)-1H-1,2,3,4-tetrazol-5-yl]butanoate (3)}

$\mathrm{Et}_{3} \mathrm{~N}(1.0 \mathrm{~mL}, 7.3 \mathrm{mmol})$ was added to a stirred mixture of methyl (2S)-2-amino-4-[1-(2-cyanoethyl)-1 $\mathrm{H}$ 1,2,3,4-tetrazol-5-yl]butanoate hydrochloride $(0.94 \mathrm{~g}, 3.3 \mathrm{mmol}$ ) (synthesis has previously been described in Chem. Pharm. Bull. 43(2) 230-235 (1995)), 5-aminopyridine-2-carboxylic acid (0.34 g, 2.4 mmol), EDC$\mathrm{HCl}(0.94 \mathrm{~g}, 4.9 \mathrm{mmol}), \mathrm{HOBt}(0.75 \mathrm{~g}, 4.9 \mathrm{mmol})$ and acetonitrile $(50 \mathrm{~mL})$. The reaction was stirred at r.t. over night and the solvent was removed under reduced pressure. The material was portioned between EtOAc $(200 \mathrm{~mL})$ and sat. $\mathrm{NaHCO}_{3}(100 \mathrm{~mL})$. The organic phase was washed with water $(25 \mathrm{~mL})$ and concentrated. The product was purified by flash chromatography (50 g silica, $5 \% \mathrm{MeOH}$ in DCM as eluent). This gave methyl (2S)-2-[(5-aminopyridin-2-yl)formamido]-4-[1-(2-cyanoethyl)-1 H-1,2,3,4-tetrazol5-yl]butanoate (0.62 g, 53\%). LCMS [M+H] ${ }^{+} \mathrm{m} / z$ 359; ${ }^{1} \mathrm{H}$ NMR (400 MHz, DMSO- $\left.d_{6}\right) \delta$ ppm 2.25 - 2.43 (m, $2 \mathrm{H}), 2.92$ - $3.00(\mathrm{~m}, 2 \mathrm{H}), 3.11$ - $3.17(\mathrm{~m}, 2 \mathrm{H}), 3.64(\mathrm{~s}, 3 \mathrm{H}), 4.58$ - $4.66(\mathrm{~m}, 3 \mathrm{H}), 6.02(\mathrm{~s}, 2 \mathrm{H}), 6.97$ (dd, $J=8.5,2.8 \mathrm{~Hz}, 1 \mathrm{H}), 7.69(\mathrm{dd}, J=8.5,0.4 \mathrm{~Hz}, 1 \mathrm{H}), 7.95(\mathrm{dd}, J=2.7,0.6 \mathrm{~Hz}, 1 \mathrm{H}), 8.66(\mathrm{~d}, J=8.4 \mathrm{~Hz}, 1 \mathrm{H})$ 
methyl (2S)-2-[(5-aminopyridin-2-yl)formamido]-4-[1-(2-cyanoethyl)-1H-1,2,3,4-tetrazol-5-yl]butanoate (0.56 $\mathrm{g}, 1.6 \mathrm{mmol})$ was dissolved in dry $\mathrm{MeCN}(2 \mathrm{~mL})$ and added to a solution of 4-nitrophenyl chloroformate $(0.31 \mathrm{~g}, 1.6 \mathrm{mmol})$ in dry MeCN $(1 \mathrm{~mL})$. The reaction was heated in a sealed tube for 1 hour at $50^{\circ} \mathrm{C}$ and for $90 \mathrm{~min}$ at $80^{\circ} \mathrm{C}$. A second solution was made by adding $5 \mathrm{M} \mathrm{NaOH}(1.9 \mathrm{~mL}, 9.4 \mathrm{mmol})$ to a stirred mixture of 2,5,6-triamino-3,4-dihydropyrimidin-4-one; sulfuric acid ( $0.75 \mathrm{~g}, 3.1 \mathrm{mmol})$ and water $(3 \mathrm{~mL})$. The warm organic mixture was added to the stirred water solution at r.t. over a period of 30 seconds. The mixture was stirred in an ice-bath for $30 \mathrm{~min}$ and the product was collected by filtration. The material was washed with water $(2 \times 1 \mathrm{~mL})$, dried and dissolved in DMSO. The intermediate ester (4) was purified by acidic prep-HPLC. The pure fractions were combined, and the solvents were removed under reduced pressure. Gave methyl (2S)-4-[1-(2-cyanoethyl)-1H-1,2,3,4-tetrazol-5-yl]-2-[(5-\{[(2,4-diamino-6-oxo-1,6dihydropyrimidin-5-yl)carbamoyl]amino\}pyridin-2-yl)formamido]butanoate $(0.63 \mathrm{~g})$. The material was dissolved in a mixture of water $(4 \mathrm{~mL})$ and $5 \mathrm{M} \mathrm{NaOH}(1.3 \mathrm{~mL})$. The reaction was stirred at r.t. for 90 min. The mixture was cooled in an ice-bath and $12 \mathrm{M} \mathrm{HCl}$ was added until $\mathrm{pH} \sim 2$ and the product was collected by filtration. The product was washed with cooled water $(2 \times 2 \mathrm{~mL})$ and dried in a vacuum oven $\left(40^{\circ} \mathrm{C}\right)$ over night. This gave (2S)-2-[(5-\{[(2,4-diamino-6-oxo-1,6-dihydropyrimidin-5-yl)carbamoyl]amino\}pyridin-2yl)formamido]-4-(1H-1,2,3,4-tetrazol-5-yl)butanoic acid (210 mg, 29\%). LCMS [M+H] ${ }^{+} \mathrm{m} / \mathrm{z} 459 ;{ }^{1} \mathrm{H}$ NMR (400 MHz, DMSO- $\left.d_{6}\right) \delta$ ppm 2.20 - $2.32(\mathrm{~m}, 1 \mathrm{H}), 2.32$ - $2.44(\mathrm{~m}, 1 \mathrm{H}), 2.87$ - $3.01(\mathrm{~m}, 2 \mathrm{H}), 4.50(\mathrm{td}, J=8.6$, 4.8 Hz, 1 H), 6.00 (br. s., 2 H), 6.25 (br. s., 2 H), 6.87 (br. s., 1 H), 7.92 (d, J=8.5 Hz, 1 H), 8.07 (d, J=7.9 Hz, 1 H), 8.69 - 8.79 (m, 2 H), 9.17 (br. s., 1 H), 10.06 (br. s., 1 H), 12.94 (br. s., 1 H), 16.00 (br. s., 1 H)

\section{Synthesis of TH9619}

\section{Methyl 5-\{(tert-butoxy)carbonyl]amino\}-3-fluoropyridine-2-carboxylate (6)}

A mixture of methyl 5-bromo-3-fluoropyridine-2-carboxylate $(2.4 \mathrm{~g}, 10 \mathrm{mmol})$, tert-butyl carbamate $(1.4 \mathrm{~g}$, $12 \mathrm{mmol}), \mathrm{Cs}_{2} \mathrm{CO}_{3}(3.9 \mathrm{~g}, 12 \mathrm{mmol})$ and dry dioxane $(50 \mathrm{~mL})$ was flashed six times with nitrogen. $\mathrm{Pd}(\mathrm{OAc})_{2}(110 \mathrm{mg}, 0.50 \mathrm{mmol})$ and $\mathrm{X}-\mathrm{Phos}(480 \mathrm{mg}, 1.0 \mathrm{mmol})$ were added and the mixture was again flashed six times with nitrogen. The sealed reaction was heated at $90^{\circ} \mathrm{C}$ for 21 hours. Brine $(50 \mathrm{~mL})$ and water $(50 \mathrm{~mL})$ were added and the mixture was extracted with EtOAc. The organic solvent was removed under reduced pressure and the product was purified by flash chromatography (EtOAc/iso-hexane 25/75 to $50 / 50$ as eluent). This gave methyl $5-\{($ tert-butoxy) carbonyl]amino\}-3-fluoropyridine-2-carboxylate (2.1 g, 76\%). LCMS $[\mathrm{M}+\mathrm{H}]^{+} \mathrm{m} / \mathrm{z} 271 ;{ }^{1} \mathrm{H}$ NMR (400 MHz, DMSO-d $\left.d_{6}\right) \delta \mathrm{ppm} 1.49$ (s, 9H), 3.85 (s, 3H), 7.92 (dd, $1 \mathrm{H}), 8.50(\mathrm{t}, 1 \mathrm{H}), 10.28(\mathrm{br} \mathrm{s}, 1 \mathrm{H})$.

\section{5-\{(tert-Butoxy)carbonyl]amino\}-3-fluoropyridine-2-carboxylic acid (7)}


$\mathrm{LiOH}(1.9 \mathrm{~g}, 79 \mathrm{mmol})$ was added to a stirred mixture of methyl 5-\{[(tert-butoxy)carbonyl]amino\}-3fluoropyridine-2-carboxylate $(3.6 \mathrm{~g}, 13 \mathrm{mmol})$, THF $(37 \mathrm{~mL})$ and water $(13 \mathrm{~mL})$. The reaction was refluxed for $30 \mathrm{~min}$. and then allowed to cool to rt. The mixture was cooled in an ice-bath and the $\mathrm{pH}$ was adjusted to $\sim 2$ with $2 \mathrm{M} \mathrm{HCl}$. The water mixture was extracted with EtOAc. The combined organic solvents were dried over $\mathrm{Na}_{2} \mathrm{SO}_{4}$ and removed in a rotavapor. This gave 5-\{[(tert-butoxy)carbonyl]amino\}-3fluoropyridine-2-carboxylic acid (2.9 g, 85\%). LCMS $[\mathrm{M}+\mathrm{H}]^{+} \mathrm{m} / \mathrm{z} 257 ;{ }^{1} \mathrm{H}$ NMR (400 MHz, DMSO- $\left.d_{6}\right) \delta \mathrm{ppm}$ 1.49 (s, 9H), $7.88(\mathrm{dd}, 1 \mathrm{H}), 8.48$ (d, 1H), 10.22 (br s, 1H), 13.17 (br s, 1H).

\section{1,5-Diethyl (2S)-2-[(5-\{(tert-butoxy)carbonyl]amino\}-3-fluoropyridin-2-yl)formamido]pentanedioate (8)}

HATU (3.7 g, $9.8 \mathrm{mmol})$ was added to a stirred mixture of 5-\{(tert-butoxy)carbonyl]amino\}-3fluoropyridine-2-carboxylic acid (2.1 g, $8.2 \mathrm{mmol}$ ), diethyl (2S)-2-aminopentanedioate hydrochloride ( $3.0 \mathrm{~g}$, $13 \mathrm{mmol}), \mathrm{Et}_{3} \mathrm{~N}(5.7 \mathrm{~mL}, 41 \mathrm{mmol})$ and dry THF $(100 \mathrm{~mL})$. The reaction was stirred for 3 hours at r.t. EtOAc $(150 \mathrm{~mL})$ was added and the mixture was washed with $0.5 \mathrm{M} \mathrm{HCl}(100 \mathrm{~mL})$ and sat. $\mathrm{NaHCO}_{3}(100$ $\mathrm{mL}$ ). The organic phase was dried over $\mathrm{Na}_{2} \mathrm{SO}_{4}$ and the solvents were removed under reduced pressure. The material was purified by flash chromatography (100g silica, 0-50\% EtOAc in iso-hexane). This gave 1,5-diethyl (2S)-2-[(5-\{(tert-butoxy)carbonyl]amino\}-3-fluoropyridin-2yl)formamido]pentanedioate ( $2.0 \mathrm{~g}, 56 \%)$. LCMS $[\mathrm{M}+\mathrm{H}]^{+} \mathrm{m} / \mathrm{z} 442 ;{ }^{1} \mathrm{H}$ NMR $\left(400 \mathrm{MHz}\right.$, DMSO- $\left.d_{6}\right) \delta \mathrm{ppm}$ 1.11 - $1.23(\mathrm{~m}, 6 \mathrm{H}), 1.49$ (s, $9 \mathrm{H}), 1.97$ - $2.19(\mathrm{~m}, 2 \mathrm{H}), 2.33$ - $2.44(\mathrm{~m}, 2 \mathrm{H}), 4.02(\mathrm{q}, J=7.1 \mathrm{~Hz}, 2 \mathrm{H}), 4.07$ $4.16(\mathrm{~m}, 2 \mathrm{H}), 4.42-4.51(\mathrm{~m}, 1 \mathrm{H}), 7.91(\mathrm{dd}, J=13.4,1.7 \mathrm{~Hz}, 1 \mathrm{H}), 8.49(\mathrm{dd}, J=1.9,1.1 \mathrm{~Hz}, 1 \mathrm{H}), 8.72(\mathrm{~d}$, $J=7.9 \mathrm{~Hz}, 1 \mathrm{H}), 10.18(\mathrm{~s}, 1 \mathrm{H})$.

\section{1,5-Diethyl (2S)-2-[(5-amino-3-fluoropyridin-2-yl)formamido]pentanedioate (9)}

TFA (10 mL) was added to a solution of 1,5-diethyl (2S)-2-[(5-\{[(tert-butoxy)carbonyl]amino\}-3fluoropyridin-2-yl)formamido]pentanedioate $(1.8 \mathrm{~g}, 4.1 \mathrm{mmol})$ in DCM $(6 \mathrm{~mL})$. The reaction was stirred at r.t. for 2 hours. The solvents were removed in a rotavapor and the material was dissolved in EtOAc (100 $\mathrm{mL}$ ). The solvent was washed with sat. $\mathrm{Na}_{2} \mathrm{CO}_{3}$, dried over $\mathrm{Na}_{2} \mathrm{SO}_{4}$ and removed under reduced pressure to afford 1,5-diethyl (2S)-2-[(5-amino-3-fluoropyridin-2-yl)formamido]pentanedioate (1.32 g, 95\%). LCMS $[\mathrm{M}+\mathrm{H}]^{+} \mathrm{m} / \mathrm{z} 342 ;{ }^{1} \mathrm{H}$ NMR (400 MHz, DMSO- $\left.d_{6}\right) \delta \mathrm{ppm} 1.11$ - $1.21(\mathrm{~m}, 6 \mathrm{H}), 1.95$ - $2.16(\mathrm{~m}, 2 \mathrm{H}), 2.30$ - 2.41 (m, 2 H), 4.02 (q, J=7.1 Hz, 2 H), 4.06 - 4.15 (m, 2 H), 4.38 - 4.48 (m, 1 H), 6.36 (s, 2 H), 6.71 (dd, J=13.9, $2.2 \mathrm{~Hz}, 1 \mathrm{H}), 7.78-7.84(\mathrm{~m}, 1 \mathrm{H}), 8.37(\mathrm{~d}, \mathrm{~J}=8.1 \mathrm{~Hz}, 1 \mathrm{H})$.

1,5-Diethyl (2S)-2-\{[5-(2-chloroacetamido)-3-fluoropyridin-2-yl]formamido\}pentanedioate (10) 
2-Chloroacetyl chloride $(3.2 \mathrm{~mL}, 40 \mathrm{mmol})$ was added to a stirred solution of 1,5-diethyl (2S)-2-[(5-amino3-fluoropyridin-2-yl)formamido]pentanedioate $(12 \mathrm{~g}, 36 \mathrm{mmol})$ and $\mathrm{Et}_{3} \mathrm{~N}(6.1 \mathrm{~mL}, 44 \mathrm{mmol})$ in DCM (100 $\mathrm{mL}$ ) at r.t. The reaction was stirred for $30 \mathrm{~min}$ and the mixture was washed with diluted $\mathrm{Na}_{2} \mathrm{CO}_{3}$. The organic phase was dried over $\mathrm{Na}_{2} \mathrm{SO}_{4}$ and removed under reduced pressure. The product was purified by flash chromatography (30-50\% EtOAc in iso-hexane as eluent). This gave 1,5-diethyl (2S)-2-\{[5-(2chloroacetamido)-3-fluoropyridin-2-yl]formamido\}pentanedioate $(11 \mathrm{~g}, 74 \%)$. LCMS [M+H] ${ }^{+} \mathrm{m} / \mathrm{z} 418 ;{ }^{1} \mathrm{H}$ $\operatorname{NMR}\left(400\right.$ MHz, DMSO- $\left.d_{6}\right) \delta$ ppm 1.13 - $1.22(\mathrm{~m}, 6 \mathrm{H}), 1.97$ - $2.19(\mathrm{~m}, 2 \mathrm{H}), 2.34$ - $2.44(\mathrm{~m}, 2 \mathrm{H}), 4.03$ (q, $J=7.2 \mathrm{~Hz}, 2 \mathrm{H}), 4.08-4.17(\mathrm{~m}, 2 \mathrm{H}), 4.37(\mathrm{~s}, 2 \mathrm{H}), 4.41-4.51(\mathrm{~m}, 1 \mathrm{H}), 8.12(\mathrm{dd}, J=13.0,1.9 \mathrm{~Hz}, 1 \mathrm{H}), 8.60$ (dd, J=1.9, 1.1 Hz, $1 \mathrm{H}), 8.83(\mathrm{~d}, J=7.9 \mathrm{~Hz}, 1 \mathrm{H}), 11.03(\mathrm{~s}, 1 \mathrm{H})$.

\section{(2S)-2-(\{5-[2-(2,4-diamino-6-oxo-1,6-dihydropyrimidin-5-yl)acetamido]-3-fluoropyridin-2- yl\}formamido)pentanedioic acid (TH9619)}

2,4-Diamino-1 H-pyrimidin-6-one (3.3 g, $26 \mathrm{mmol}), \mathrm{NaHCO}_{3}(2.2 \mathrm{~g}, 26 \mathrm{mmol})$ and $\mathrm{Nal}(14 \mathrm{~g}, 96 \mathrm{mmol})$ were added to a stirred solution of 1,5-diethyl (2S)-2-\{[5-(2-chloroacetamido)-3-fluoropyridin-2yl]formamido\}pentanedioate $(10 \mathrm{~g}, 24 \mathrm{mmol})$ in DMF $(75 \mathrm{~mL})$. The reaction was stirred in a sealed flask at r.t. for 2 days. Brine $(225 \mathrm{~mL})$ was added to the reaction and the intermediate ester was collected by filtration and washed with water and MeCN. LCMS $[M+H]^{+} m / z 508$. The material was suspended in water $(200 \mathrm{~mL})$ and $5 \mathrm{M} \mathrm{NaOH}(29 \mathrm{~mL}, 140 \mathrm{mmol})$ was added. The reaction was stirred at r.t. for $30 \mathrm{~min}$. The $\mathrm{pH}$ was adjusted to $\sim 3$ with $1 \mathrm{M} \mathrm{HCl}$ and the product was collected by filtration and washed with water and MeCN. The material was dried under vacuum $\left(40^{\circ} \mathrm{C}\right)$ over night. This gave (2S)-2-( $\{5-[2-(2,4-d i a m i n o-6-$ oxo-1,6-dihydropyrimidin-5-yl)acetamido]-3-fluoropyridin-2-yl\}formamido)pentanedioic acid (6.5 g, 60\%). LCMS $[\mathrm{M}+\mathrm{H}]^{+} \mathrm{m} / \mathrm{z} 452 ;{ }^{1} \mathrm{H}$ NMR (400 MHz, DMSO- $\left.d_{6}\right) \delta$ ppm $1.91-2.03(\mathrm{~m}, 1 \mathrm{H}), 2.03-2.15(\mathrm{~m}, 1 \mathrm{H}), 2.25$ - 2.34 (m, 2 H), 3.33 (s, 2 H), 4.39 (td, J=8.5, 5.1 Hz, 1 H), 5.97 (s, 2 H), 6.15 (br. s., 2 H), 8.12 (dd, J=13.5, 2.0 Hz, 1 H), 8.57 - 8.61 (m, 1 H), 8.64 (d, J=7.9 Hz, 1 H), 10.05 (br. s., 1 H), 10.65 (s, 1 H), 12.44 (br. s., 2 H). $[\mathrm{a}]^{25}{ }_{\mathrm{D}}+10.9^{\circ}\left(\mathrm{c}=0.13,0.2 \mathrm{M} \mathrm{Na}_{2} \mathrm{CO}_{3} \mathrm{aq}\right)$.

\section{Synthesis of TH11737}

\section{Methyl 5-amino-3-fluoropyridine-2-carboxylate (12)}

TFA (2 mL) was added to a solution of $5-\{[$ (tert-butoxy) carbonyl]amino\}-3-fluoropyridine-2-carboxylic acid $(190 \mathrm{mg}, 0.70 \mathrm{mmol})$ in DCM $(2 \mathrm{~mL})$. The reaction was stirred at r.t. for 2 hours. The solvents were removed under reduced pressure and the material was added EtOAc $(10 \mathrm{~mL})$. The solvent was washed with sat. $\mathrm{Na}_{2} \mathrm{CO}_{3}$, dried over $\mathrm{Na}_{2} \mathrm{SO}_{4}$ and removed under reduced pressure to afford methyl 5-amino-3fluoropyridine-2-carboxylate (110 mg, 92\%). LCMS $[\mathrm{M}+\mathrm{H}]^{+} \mathrm{m} / \mathrm{z} 171 ;{ }^{1} \mathrm{H}$ NMR (400 MHz, DMSO- $\left.d_{6}\right) \delta \mathrm{ppm}$ 3.76 (s, 3 H), 6.54 (s, 2 H), 6.65 - $6.73(m, 1$ H), 7.81 - $7.86(m, 1$ H). 


\section{Methyl 5-(2-chloroacetamido)-3-fluoropyridine-2-carboxylate (13)}

2-Chloroacetylchloride $(0.57 \mathrm{~mL}, 7.1 \mathrm{mmol})$ was added to a stirred solution of methyl 5-amino-3fluoropyridine-2-carboxylate $(0.93 \mathrm{~g}, 5.5 \mathrm{mmol})$ and $\mathrm{Et}_{3} \mathrm{~N}(2.3 \mathrm{~mL}, 16 \mathrm{mmol})$ in dry THF $(50 \mathrm{~mL})$ at r.t. The reaction was stirred at r.t. for 30 min and sat. $\mathrm{Na}_{2} \mathrm{CO}_{3}(20 \mathrm{~mL})$ was added. The mixture was extracted with EtOAc $(100 \mathrm{~mL})$. The organic phase was dried over $\mathrm{Na}_{2} \mathrm{SO}_{4}$ and removed under reduced pressure. The crude material was suspended in $\mathrm{MeOH}(5 \mathrm{~mL})$ and product with improved purity was collected by filtration. Gave methyl 5-(2-chloroacetamido)-3-fluoropyridine-2-carboxylate (0.69 g, 51\%). LCMS [M+H] $\mathrm{m} / \mathrm{z} 247 ;{ }^{1} \mathrm{H}$ NMR (400 MHz, DMSO- $\left.d_{6}\right) \delta \mathrm{ppm} 3.86(\mathrm{~s}, 3 \mathrm{H}), 4.37$ (s, $\left.2 \mathrm{H}\right), 8.18$ (dd, $J=12.9,2.0 \mathrm{~Hz}, 1 \mathrm{H}$ ), $8.59(\mathrm{dd}, \mathrm{J}=2.0,1.2 \mathrm{~Hz}, 1 \mathrm{H}), 11.10(\mathrm{~s}, 1 \mathrm{H})$.

\section{Methyl 5-[2-(2,4-diamino-6-oxo-1,6-dihydropyrimidin-5-yl)acetamido]-3-fluoropyridine-2-carboxylate (14)}

2,4-Diamino-1 H-pyrimidin-6-one (250 mg, 2.0 mmol), $\mathrm{NaHCO}_{3}(170 \mathrm{mg}, 2.0 \mathrm{mmol}$ ) and $\mathrm{Nal}(820 \mathrm{mg}, 5.5$ $\mathrm{mmol}$ ) were added to a stirred solution of methyl 5-(2-chloroacetamido)-3-fluoropyridine-2-carboxylate (450 mg, $1.8 \mathrm{mmol})$ in DMF (1 mL). The reaction was stirred in a sealed flask at r.t. over night. DMF (1 $\mathrm{mL})$ and water $(2 \mathrm{~mL})$ were added to the reaction mixture and the product was collected by filtration and washed with water, 1:1 DMF/water and MeCN. The material was dried under vacuum $\left(40^{\circ} \mathrm{C}\right)$ for 30 min. Gave methyl 5-[2-(2,4-diamino-6-oxo-1,6-dihydropyrimidin-5-yl)acetamido]-3-fluoropyridine-2-carboxylate (500 mg, 82\%). LCMS [M+H] ${ }^{+} \mathrm{m} / \mathrm{z} 337 ;{ }^{1} \mathrm{H}$ NMR (400 MHz, DMSO- $\left.d_{6}\right) \delta$ ppm 3.32 (s, $\left.2 \mathrm{H}\right), 3.84(\mathrm{~s}, 3 \mathrm{H})$, 5.84 (br. s., 2 H), 6.37 (br. s., 2 H), 8.16 (dd, J=13.3, 2.0 Hz, 1 H), 8.53 - 8.56 (m, 1 H), 10.90 (br. s., 2 H).

\section{5-[2-(2,4-Diamino-6-oxo-1,6-dihydropyrimidin-5-yl)acetamido]-3-fluoropyridine-2-carboxylic acid (15)}

$1 \mathrm{M} \mathrm{NaOH}(5 \mathrm{~mL})$, water $(5 \mathrm{~mL})$ and methyl 5-[2-(2,4-diamino-6-oxo-1,6-dihydropyrimidin-5yl)acetamido]-3-fluoropyridine-2-carboxylate $(500 \mathrm{mg}, 1.5 \mathrm{mmol})$ were stirred at r.t. for $30 \mathrm{~min}$. The reaction mixture was filtered and the $\mathrm{pH}$ was adjusted to $\sim 2$ with $2 \mathrm{M}$ and $1 \mathrm{M} \mathrm{HCl}$. The product was collected by filtration and washed with water and MeCN. Gave 5-[2-(2,4-diamino-6-oxo-1,6dihydropyrimidin-5-yl)acetamido]-3-fluoropyridine-2-carboxylic acid (240 mg, 47\%). LCMS [M+H] ${ }^{+} \mathrm{m} / \mathrm{z}$ 323; ${ }^{1} \mathrm{H}$ NMR (400 MHz, DMSO- $d_{6}$ ) $\delta$ ppm 3.33 (s, $2 \mathrm{H}$ ), 5.95 (s, $\left.2 \mathrm{H}\right), 6.11$ (s, $2 \mathrm{H}$ ), 8.13 (dd, J=13.3, $1.9 \mathrm{~Hz}$, 1 H), 8.56 - 8.60 (m, 1 H), 9.99 (br. s., 1 H), 10.65 (s, 1 H), 13.16 (br. s., 1 H).

(2R)-2-(\{5-[2-(2,4-diamino-6-oxo-1,6-dihydropyrimidin-5-yl)acetamido]-3-fluoropyridin-2ylfformamido)pentanedioic acid (TH11737) 
$\mathrm{Et}_{3} \mathrm{~N}(0.22 \mathrm{~mL}, 1.6 \mathrm{mmol}), \mathrm{HOBt}(61 \mathrm{mg}, 0.465 \mathrm{mmol})$ and $\mathrm{EDC}-\mathrm{HCl}(89 \mathrm{mg}, 0.465 \mathrm{mmol})$ were added to a stirred mixture of 5-[2-(2,4-diamino-6-oxo-1,6-dihydropyrimidin-5-yl)acetamido]-3-fluoropyridine-2-

carboxylic acid (100 mg, $0.31 \mathrm{mmol}$ ), 1,5-dimethyl (2R)-2-aminopentanedioate hydrochloride (79 mg, 0.37 $\mathrm{mmol})$ and DMSO $(3 \mathrm{~mL})$. The reaction was stirred in a sealed tube at r.t. over night. The intermediate ester (16) was purified by acidic prep-HPLC. The pure fractions were combined and the solvents were removed under reduced pressure. Gave 1,5-dimethyl (2R)-2-(\{5-[2-(2,4-diamino-6-oxo-1,6-dihydropyrimidin5-yl)acetamido]-3-fluoropyridin-2-yl\}formamido)pentanedioate (45 mg). LCMS [M+H] $]^{+} \mathrm{m} / z$ 480. The material was dissolved in $1 \mathrm{M} \mathrm{NaOH}(1.5 \mathrm{~mL})$. The reaction was stirred at r.t. for 10 min. $1 \mathrm{M} \mathrm{HCl}$ was added until $\mathrm{pH} \sim 2$ and the product was collected by filtration. The product was washed with water and dried in a vacuum oven $\left(40^{\circ} \mathrm{C}\right)$ over night. Gave (2R)-2-(\{5-[2-(2,4-diamino-6-oxo-1,6-dihydropyrimidin-5yl)acetamido]-3-fluoropyridin-2-yl\}formamido)pentanedioic acid (18 mg, 13\%). LCMS [M+H] ${ }^{+} \mathrm{m} / \mathrm{z} 452 ;{ }^{1} \mathrm{H}$ NMR (400 MHz, DMSO- $\left.d_{6}\right) \delta$ ppm 1.89 - $2.03(\mathrm{~m}, 1 \mathrm{H}), 2.05$ - $2.17(\mathrm{~m}, 1 \mathrm{H}), 2.26$ - $2.34(\mathrm{~m}, 2 \mathrm{H}), 3.35(\mathrm{~s}, 2$ H), 4.36 - 4.46 (m, 1 H), 6.22 (br. s., 2 H), 6.54 (br. s., 2 H), 8.11 (dd, J=13.3, 2.0 Hz, 1 H), 8.61 (dd, J=1.8, $1.2 \mathrm{~Hz}, 1 \mathrm{H}$ ), 8.65 (d, J=8.1 Hz, 1 H), 10.35 (br. s., $1 \mathrm{H}$ ), 10.66 (s, $1 \mathrm{H}), 12.40$ (br. s., $2 \mathrm{H}$ ). [a] ${ }^{25}{ }_{\mathrm{D}}-11.6^{\circ}$ (c = $\left.0.13,0.2 \mathrm{M} \mathrm{Na}_{2} \mathrm{CO}_{3} \mathrm{aq}\right)$.

$\underline{\text { Abbreviations }}$

aq

aqueous

$\mathrm{Cs}_{2} \mathrm{CO}_{3} \quad$ cesium carbonate

DCM dichloromethane

DMF dimethylformamide

DMSO dimethylsulfoxide

EDC N-(3-dimethylaminopropyl)-N'-ethylcarbodiimide

$\mathrm{Et}_{3} \mathrm{~N} \quad$ triethylamine

EtOAc ethyl acetate

$\mathrm{HCl} \quad$ hydrochloride

HATU 1-[Bis(dimethylamino)methylene]-1H-1,2,3-triazolo[4,5-b]pyridinium 3-oxid hexafluorophosphate

HOBt 1-hydroxybenzotriazole

HPLC high-performance liquid chromatography 
LCMS liquid-chromatography electrospray mass spectroscopy

$\mathrm{LiOH} \quad$ lithium hydroxide

$\mathrm{MeCN} \quad$ acetonitrile

$\mathrm{MeOH} \quad$ methanol

$\mathrm{NaHCO}_{3} \quad$ sodium bicarbonate

$\mathrm{NaOH} \quad$ sodium hydroxide

Nal sodium iodide

$\mathrm{Na}_{2} \mathrm{CO}_{3} \quad$ sodium carbonate

$\mathrm{Na}_{2} \mathrm{SO}_{4} \quad$ sodium sulfate

NMR nuclear magnetic resonance

$\mathrm{Pd}(\mathrm{OAc})_{2} \quad$ palladium(II) acetate

r.t. room temperature

sat. saturated

TFA trifluoroacetic acid

THF tetrahydrofuran

Stable isotope tracing and metabolite extraction. Stable isotope tracing experiments with $\left[\mathrm{U}-{ }^{13} \mathrm{C}\right]$-serine tracer (Cambridge Isotope Laboratories) were performed in customized serine-, glycine-, and glutaminefree RPMI 1640 (Cell Culture Technologies, Switzerland). Tracer medium was supplemented with $400 \mu \mathrm{M}$ glycine, $2 \mathrm{mM}$ glutamine, $17 \mathrm{mM}$ glucose, $400 \mu \mathrm{M}\left[\mathrm{U}-{ }^{13} \mathrm{C}\right]-$ serine tracer, $1 \% \mathrm{P} / \mathrm{S}$, and $5 \% \mathrm{FBS}$. 300,000 HL60 cells were seeded in 12-well plates in triplicates for each experimental condition in $1 \mathrm{ml}$ RPMI tracer medium, treated as indicated, and cultured for $24 \mathrm{~h}$. Residual cell seeding solution was counted and cell size was determined to calculate packed cell volume (PCV) of total cells in $\mathrm{pL}$ at the start of each tracing experiment. After $24 \mathrm{~h}$, triplicate wells per condition were counted and cell size was determined to calculate PCV at the end of the tracing experiment. All following steps for metabolite extraction were carried out on ice. First, medium of all conditions in triplicates was collected by centrifugation. To be able to determine the basal medium composition, tracer medium without cells was incubated in parallel throughout the experiment in triplicates in 12 wells. All collected media were centrifuged at $300 \mathrm{~g}$ for 5 min to remove residual cellular debris. Supernatant was collected and stored at $-20{ }^{\circ} \mathrm{C}$ to allow for 
subsequent analysis of formate exchange rates from the medium. Formate extraction, derivatization, and quantification was performed using GC-MS analysis as previously described ${ }^{28}$. For intracellular metabolite extraction after [U- $\left.{ }^{13} \mathrm{C}\right]$-serine tracing, pelleted $\mathrm{HL}-60$ cells were washed with $1 \mathrm{ml}$ cold PBS and subsequently resuspended in $400 \mu \mathrm{l}$ ice-cold extraction solvent (5:3:2 $\left.\mathrm{MeOH} / \mathrm{ACN} / \mathrm{H}_{2} \mathrm{O}\right)$. Intracellular metabolites were extracted by shaking at $4{ }^{\circ} \mathrm{C}$ for $10 \mathrm{~min}$. After a final centrifugation, supernatant was collected, stored at $-80^{\circ} \mathrm{C}$, and submitted to LC-MS analysis of intracellular metabolite labeling. LC-MS analysis of nucleotides was detailed in BioRxiv Preprint Kiweler et al. 2021 (https://doi.org/10.1101/2021.05.27.445928).

Genomic 2'-deoxyuridine (dU) measurements. Cells were lysed by passing through $21 \mathrm{G}$ and $23 \mathrm{G}$ syringe needles and subsequent incubation at $37^{\circ} \mathrm{C}$ for $1 \mathrm{~h}$ with $1000 \mathrm{RPM}$ shaking in a buffer containing $10 \mathrm{mM}$ Tris- $\mathrm{HCl}$ (pH 8.0), $10 \mathrm{mM} \mathrm{NaCl}, 1 \%$ SDS, $100 \mathrm{mM}$ DTT, $0.1 \mathrm{mg} / \mathrm{mL}$ proteinase $\mathrm{K}$ (Worthington Biochemical), $0.1 \mathrm{mg} / \mathrm{mL}$ RNase A (Sigma-Aldrich), $50 \mu \mathrm{M}$ tetrahydrouridine (THU, Merck Millipore). DNA was subsequently extracted from the lysates with 25:24:1 phenol:chloroform:isoamyl alcohol, followed by two washes with 24:1 chloroform:isoamyl alcohol and isopropanol precipitation using $10 \mathrm{M}$ ammonium acetate to precipitate the DNA. RNA and free nucleotides were then removed from the DNA samples by treatment with $4 \mu \mathrm{g}$ RNase $A$ in $10 \mathrm{mM}$ ammonium bicarbonate $(\mathrm{pH} 7.0), 10 \mathrm{mM} \mathrm{MgCl}_{2}$ for 30 min at $37^{\circ} \mathrm{C}$, followed by a subsequent isopropanol precipitation. Next, the DNA samples were hydrolyzed and dephosphorylated to single nucleosides as previously described (Galashevskaya, A. et al. DNA Repair. 2013 Sep;12(9):699-706. doi: 10.1016/j.dnarep.2013.05.002). DNA was hydrolyzed to nucleosides by treatment with $0.8 \mathrm{U}$ Nuclease P1 (Sigma-Aldrich), $80 \mathrm{U}$ Benzonase ${ }^{\circledR}$ Nuclease (Santa Cruz Biotechnology), and 7.5 U Antarctic Phosphatase (New England Biolabs) in $50 \mu$ reactions containing $10 \mathrm{mM}$ ammonium acetate (pH 5.5), $1 \mathrm{mM} \mathrm{MgCl}, 0.1 \mathrm{mM} \mathrm{ZnCl}_{2}$ and $240 \mu \mathrm{M}$ THU for 60 min at $37^{\circ} \mathrm{C}$. Enzymes were then precipitated and removed from the reactions by adding three volumes of icecold acetonitrile to the reactions, incubating for $10 \mathrm{~min}$ on ice, centrifugation at 16,000 RCF for $30 \mathrm{~min}$ at $4{ }^{\circ} \mathrm{C}$. The supernatants were transferred to new tubes and lyophilized until dry. To separate dU from dC, the samples were redissolved in water and fractionated on an Agilent 1200 HPLC system (with a UV detector set to $260 \mathrm{~nm}$ to identify the canonical nucleosides) and a mixed mode Primesep 200 column (2.1 $\mathrm{mm} \times 150 \mathrm{~mm}, 5 \mu \mathrm{m}$, SieLC) kept at $30^{\circ} \mathrm{C}$ using a flow rate of $0.4 \mathrm{~mL} / \mathrm{min}$ and water and acetonitrile as mobile phase, each containing $0.1 \%$ formic acid, as the mobile phase. The 12-min-long HPLC gradient was as follows: $5 \%$ acetonitrile for $30 \mathrm{~s}$, ramp to $35 \%$ acetonitrile by $1.5 \mathrm{~min}$ to $2.5 \mathrm{~min}$, and return to $5 \%$ acetonitrile by $2.51 \mathrm{~min}$. The dU-containing fractions were collected from 1.6-1.7 $\mathrm{min}$ and vacuum centrifuged until dry. The pellets were redissolved in water and analyzed by LC-MS/MS using a reverse phase column ( $2.1 \mathrm{~mm} \times 150 \mathrm{~mm}, 1.8 \mu \mathrm{m}$, EclipsePlusC18 RRHD, Agilent Technologies) kept at $25^{\circ} \mathrm{C}$ with a flow rate of $0.3 \mathrm{~mL} / \mathrm{min}$ on a 1290 Infinity II HPLC coupled to a 6495 Triple Quadrupole mass spectrometer with an electrospray ion source (Agilent Technologies). Water and methanol were used as the mobile phase, each containing $0.1 \%$ formic acid. The 13-min-long HPLC gradient was as follows: $5 \%$ methanol for $3 \mathrm{~min}$, ramp to $13 \%$ methanol by $3.5 \mathrm{~min}$, ramp to $17 \%$ methanol by $5.5 \mathrm{~min}$ to $7 \mathrm{~min}$ and return to $5 \%$ methanol by $8 \mathrm{~min}$. Analysis was performed in positive ionization multiple reaction monitoring mode, using the mass transitions $229.08 \rightarrow 113.0$ and $232.08 \rightarrow 116.0$ for $2^{\prime}$-deoxyuridine 
(dU), ${ }^{13} \mathrm{C}^{15} \mathrm{~N}_{2}$-dU, respectively. Unmodified nucleosides were measured on an API5500 triple quadrupole mass spectrometer (Applied Biosystems) with a reverse phase column at room temperature (Zorbax SBC18 $2.1 \mathrm{~mm} \times 150 \mathrm{~mm}, 3.5 \mu \mathrm{m}$, Agilent Technologies). The HPLC method used a flow rate of $300 \mu \mathrm{L} / \mathrm{min}$ with an isocratic flow of $25 \% \mathrm{~B}$ for 2 min with the column heated to $40{ }^{\circ} \mathrm{C}$. The mass transitions used were $252.1 \rightarrow 136,228.1 \rightarrow 111.9,268.1 \rightarrow 152$, and $243.1 \rightarrow 127 \mathrm{~m} / \mathrm{z}$ for $\mathrm{dA}$, dC, dG, and dT, respectively. 